\title{
Hypothalamo-pituitary hormone insufficiency associated with cleft lip and palate
}

\author{
ABRAHAM ROITMAN AND ZVI LARON \\ From the Institute of Pediatric and Adolescent Endocrinology, Beilinson Medical Center, Petah Tikva, and \\ Sackler School of Medicine, Tel Aviv University, Israel
}

SUMmary Two male patients with congenital cleft lip and palate first seen at ages 10.2 and 21.5 years presented with typical signs of hypothalamic-anterior pituitary hormone deficiencies. They were found to lack GH, LH, and FSH and to be partially deficient in TSH and ACTH. Several congenital defects may explain this rare syndrome affecting midline structures in the proximity of the maldeveloped palate, including Rathke's pouch, which migrates distally to develop into the anterior pituitary.

The association of cleft lip and/or palate with pituitary hormone deficiency has been reported in only 8 patients (Prüsener, 1933; Brewer, 1957; Francés et al., 1966; Zimmerman et al., 1967; Laron et al., 1969; Zuppinger et al., 1971). The pathogenesis of this syndrome has been suggested to stem from the close relationship between midline facial structures and the Rathke's pouch in early fetal development (Tondury, 1976). We report two patients with this rare combination of congenital malformations in whom an evaluation of the hypothalamic-pituitary function was obtained.

\section{Case reports}

Case 1. A boy of nonconsanguineous parents of Jewish-Iraqi origin was born with a cleft lip and palate which were surgically corrected in several

Abbreviations

ACTH: Adrenocorticotropic hormone FSH: Follicle-stimulating hormone

GH: Growth hormone

ITT: Insulin tolerance test

LH: Luteinising hormone

11-OHCS: 11-Hydroxycorticosteroid

T4: $\quad$ Thyroxine

TRH: Thyroid-releasing hormone

TSH: Thyroid-stimulating hormone stages. Pregnancy was uneventful as was delivery. Birthweight was $4500 \mathrm{~g}$. There were no neonatal complications. During early childhood there were no serious illnesses and mental development was normal but there was, apparently, growth retardation from infancy. At age 7 years secondary hypothyroidism was diagnosed and treatment with thyroid extract was initiated; despite this there was no subsequent improvement in his growth rate.

When referred to our clinic at age $10 \cdot 2$ years he was found to be an alert boy who looked young for his age. He was very short but of proportional build (Table 1), and exhibited several clinical features suggestive of a deficiency of GH and gonadotrophins including acromicria, frontal bossing, overcrowding of teeth, and a small penis $(3 \times 0.8 \mathrm{~cm})($ Laron, 1969 ;

Table 1 Findings in 2 patients with cleft lip palate

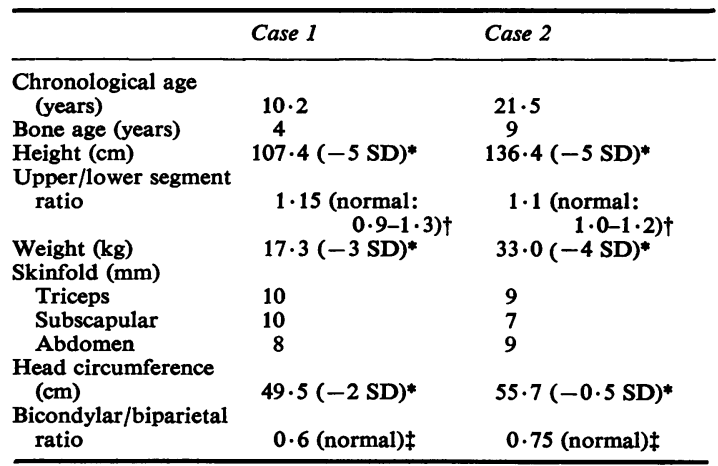

*SD height and weight calculated from the 50th centile for age; †Arad and Laron, 1978; †Scharf and Laron, 1972. 
Laron et al., 1977). The testicular volume was $1.5 \mathrm{ml}$. Neurological examination was unremarkable and in repeated EEGs a slight irregularity was noted on one occasion. $X$-ray of the sella was normal, with no evidence of intracranial calcifications. Routine chemistry of blood and urine, including specific gravity of urine and osmolality was normal. Fasting blood sugar was repeatedly normal.

The endocrinological evaluation (Table 2) was considered to indicate that the boy had multiple pituitary hormone deficiencies, and lacked $\mathrm{GH}$, TSH, and gonadotrophins, and also, to a partial extent, ACTH. The addition of GH to the thyroxine treatment which he was already receiving elicited an excellent response in linear growth; during the next year he grew $12 \mathrm{~cm}$ (Figure). At age 12.5 years there are, as expected, no signs of puberty, and it is planned to administer sex hormones next year.

Case 2. A baby boy of consanguineous parents of Jewish-Sephardic origin, was born by breech delivery and suffered neonatal asphyxia, with a birth weight of $3250 \mathrm{~g}$. His cleft lip and palate were corrected in several stages during early childhood. From the beginning his psychomotor development was retarded (IQ 50) and eventually he attended a special school for mental defectives. From infancy he was also noted to be of short stature. Hypopituitarism was suspected at age 6 years but due to neglect by the family it was not until he was 14 years that he received substitution treatment with thyroid extract, but with no improvement in his growth rate.

When referred to our clinic at the age of 21.5 years he was obviously mentally retarded. He was short (Table 1) with several features typical of pituitary hormone insufficiency. He had a short systolic murmur, considered to be functional, and there was

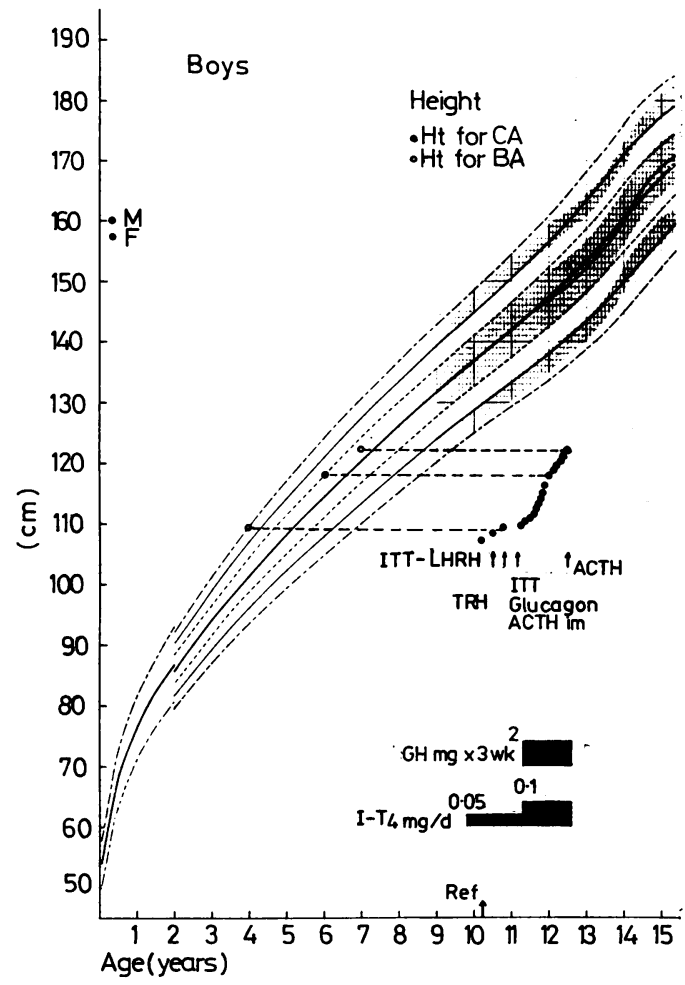

Figure (Case 1). Linear growth during treatment with L-thyroxine alone and combined with $\mathrm{GH}$.

Arrows indicate age at which endocrine tests were performed.

a simian palmar crease on both hands. Routine blood chemistry, specific gravity of urine, and $x$-ray of the skull and skeleton were normal. The endocrinological evaluation (Table 2) disclosed a deficiency in GH, TSH, ACTH, and gonadotrophins.

Table 2 Endocrinological evaluation of 2 males with cleft lip and palate and hypothalamo-pituitary insufficiency

\begin{tabular}{|c|c|c|c|c|c|c|}
\hline & \multirow[t]{2}{*}{ Hormonal function } & \multirow[t]{2}{*}{ Stimulation } & \multicolumn{2}{|l|}{ Case 1} & \multicolumn{2}{|l|}{ Case 2} \\
\hline & & & Basal & Peak & Basal & Peak \\
\hline Pituitary & GH (ng/ml) & $\begin{array}{l}\text { ITT } \\
\text { IV glucagon }\end{array}$ & $\begin{array}{l}1 \cdot 6 \\
0 \cdot 5\end{array}$ & $\begin{array}{l}2 \\
0 \cdot 5\end{array}$ & $<1$ & $<1$ \\
\hline & Prolactin (ng/ml) & TRH & $8 \cdot 4$ & 32 & $11,(47)$ & 47 \\
\hline Pituitary-thyroid axis & $\begin{array}{l}\text { T4 }(\mu \mathrm{g} / 100 \mathrm{ml}) \\
\text { TSH }(\mathrm{mU} / 1) \\
\text { I131 uptake } \\
2 \text { hours } \\
24 \text { hours }\end{array}$ & TRH & $\begin{array}{c}1 \\
15 \cdot 4 \\
16 \% \\
33 \%\end{array}$ & 50 & $\begin{array}{l}1 \cdot 8 \\
11 \cdot 2 \\
4 \cdot 6 \% \\
13 \%\end{array}$ & $19 \cdot 3$ \\
\hline Pituitary-adrenal axis & $11-$ OHCS $(\mu \mathrm{g} / 100 \mathrm{ml})$ & $\begin{array}{l}\text { ACTH 1-24 } \\
\text { ITT }\end{array}$ & $5 \cdot 3$ & $\begin{array}{l}16 \\
6 \cdot 5\end{array}$ & $\begin{array}{l}4 \\
9 \cdot 7\end{array}$ & $\begin{array}{l}13 \\
5 \cdot 5\end{array}$ \\
\hline Pituitary-gonadal axis & $\begin{array}{l}\mathrm{LH}(\mathrm{mIU} / \mathrm{ml}) \\
\text { FSH }(\mathrm{mIU} / \mathrm{ml}) \\
\text { Testosterone }(\mathrm{ng} / 100 \mathrm{ml})\end{array}$ & $\begin{array}{l}\text { LH-RH } \\
\text { LH-RH } \\
-\end{array}$ & $\begin{array}{l}0.36 \\
0.5 \\
-\end{array}$ & $\begin{array}{l}0 \cdot 74 \\
0 \cdot 5\end{array}$ & $<10^{0.5^{0.25}}$ & $\begin{array}{l}0.42 \\
0.5\end{array}$ \\
\hline
\end{tabular}

GH, gonadoptrophins, ACTH, and adrenal hormone secretion were measured during L-thyroxine replacement therapy.

Conversion: Traditional units to $S I-\mathrm{T} 4: 1 \mu \mathrm{g} / 100 \mathrm{ml} \simeq 12.87 \mathrm{nmol} / 1 ;$ testosterone: $1 \mathrm{ng} / \mathrm{ml} \simeq 3.467 \mathrm{nmo} ! / 1$. 


\section{Discussion}

In these two patients the deficiency of multiple pituitary hormones (GH, LH, FSH, ACTH, TSH) was clearly proved by the clinical findings and laboratory tests. In Case 1 the normal response of prolactin to TRH is suggestive of damage to the hypothalamic area with the pituitary cells remaining intact. The findings of high basal levels of TSH, despite the inactivity of the thyroid, and the exaggerated response to TRH stimulation are similar to the findings in a group of patients with hypothalamic hypothyroidism described by Illig et al. (1975) who explained this phenomenon as resulting from the production of a biologically inactive TSH molecule or end-organ hyposensitivity to TSH. All these observations fit in well with an embryological origin of the syndrome, affecting midline structures in the proximity of the maldeveloped palate, such as Rathke's pouch which migrates distally to develop into the anterior pituitary and connects with the hypothalamus.

In Case 2 additional damage to the pituitary may have been incurred during the breech delivery, with traction of the baby causing partial stalk section. An association between pituitary insufficiency and breech delivery has been noted by others (Rona and Tanner, 1977; Zadik et al., unpublished). Alternatively, the main cause of the mental retardation may have been the asphyxial damage incurred during the baby's delivery. However, minor intellectual deficit has been associated with idiopathic pituitary insufficiency and even with isolated congenital GH deficiency (Frankel and Laron, 1968); this patient was also born of consanguineous parents.

The anterior pituitary insufficiency associated with cleft lip and palate has been found to be of various degrees, depending upon the extent of the teratological lesion. Of the 8 patients previously reported, a complete endocrinological evaluation was carried out only in 4 . The single case described

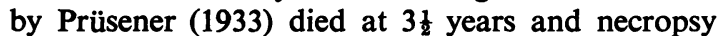
showed compression of the anterior and posterior pituitary by a cyst. In the case described by Brewer (1957), death occurred $4 \frac{1}{2}$ hours after birth, and there was aplasia of the pituitary gland. The two patients reported by Francés et al. (1966) showed clinical signs suggestive of a selective GH deficiency but no determination of hormone levels was made. The patient reported by Zimmerman et al. (1967) had a total lack of gonadoptrophins and a partial GH deficiency, although his growth was apparently normal. The patient described by Zuppinger et al. (1971) was found to have a defective secretion of both anterior and posterior pituitary hormones, and a coloboma of the right choroid and optic nerve. Of the two children previously reported from our clinic (Laron et al., 1969), one had essentially no response to stimulation with arginine or insulin-hypoglycaemia, whereas the other gave a normal response to arginine but none to insulin, both having a partial GH deficiency.

There have been reports of syndromes characterised by cleft lip and palate associated with hypospadias and/or cryptorchidism (Christian et al., 1969; Opitz, et al. 1969; Abruzzo and Erickson, 1977), but in none of these 3 cases was endocrinological evaluation made, so that the short stature in the case of Abruzzo and Erickson may well have been due to GH deficiency.

The association between cleft lip and palate and a hypothalamic-pituitary insufficiency may be less rare than at present considered. Any child with a cleft lip or palate who also shows slow development, growth retardation, or anomalies of the gonads or genitalia merits comprehensive endocrinological investigation.

We thank Dr Athalia Pertzelan for critical discussions and Mrs Ruth Fredkin for assistance in editing the manuscript.

\section{References}

Abruzzo, M. A., and Erickson, R. P. (1977). A new syndrome of cleft palate associated with coloboma, hypospadias, deafness, short stature, and radial synostosis. Journal of Medical Genetics, 14, 76-80.

Arad, I., and Laron, Z. (1978). Standards for upper/lower body segment ratio (sitting height/sub-ischial leg length) from birth to 18 years in girls and boys. Acta medica auxologica, 9 (in press).

Brewer, D. B. (1957). Congenital absence of the pituitary gland and its consequences. Journal of Pathology and Bacteriology, 73, 59-67.

Christian, J. C., Bixler, D., Blythe, S. C., and Merritt, A. D. (1969). Familial telecanthus with associated congenital anomalies. Birth Defects: Original Article Series, 5, No. 2, 82-85.

Francés, J. M., Knorr, D., Martinez, R., and Neuhäuser, G. (1966). Hypophysärer Zwergwuchs bei Lippen-KieferSpalte. Helvetica paediatrica acta, 21, 315-322.

Frankel, J. J., and Laron, Z. (1968). Psychological aspects of pituitary insufficiency in children and adolescents with special reference to growth hormone. Israel Journal of Medical Sciences, 4, 953-961.

Illig, R., Krawczynska, H., Torresani, T., and Prader, A. (1975). Elevated plasma TSH and hypothyroidism in children with hypothalamic hypopituitarism. Journal of Clinical Endocrinology and Metabolism, 41, 722-728.

Laron, Z. (1969). The hypothalamus and the pituitary gland (hypophysis). In Paediatric Endocrinology, pp. 35-111. Edited by D. Hubble. Blackwell: Oxford.

Laron, Z., Kaushanski, A., and Josefsberg, Z. (1977). Penile size and growth in children and adolescents with isolated gonadotrophin deficiency (IGuD). Clinical Endocrinology, 6, 265-270.

Laron, Z., Taube, E., and Kaplan, I. (1969). Pituitary growth hormone insufficiency associated with cleft lip and palate. Helvetica paediatrica acta, 24, 576-581. 
Opitz, J. M., Summitt, R. L., and Smith, D. W. (1969). The BBB syndrome-familial telecanthus with associated congenital anomalies. Birth Defects; Original Article Series 5, No. 2, 86-94.

Prüsener, L. (1933). Hypophysäre Wachstumshemmung mit Kachexie beim Kinde. Zeitschrift für menschliche Vererbungs-und Konstitutionslehre, 17, 215-224.

Rona, R. J., and Tanner, J. M. (1977). Aetiology of idiopathic growth hormone deficiency in England and Wales. Archives of Disease in Childhood, 52, 197-208.

Scharf, A., and Laron, Z. (1972). Skull changes in pituitary dwarfism and the syndrome of familial dwarfism with high plasma immunoreactive growth hormone. A roentgenologic study. Hormone and Metabolic Research, 4, 93-97.

Tondury, G. (1976). Zur Genese der Lippen-Kiefer-Gaumen-
Spalten. Zeitschrift für Kinderheilkunde, 19, Supplement, 5-22.

Zimmerman, T. S., White, M. G., Daughaday, W. H., and Goetz, F. C. (1967). Hypopituitarism with normal or increased height. American Journal of Medicine, 42, 146150.

Zuppinger, K. A., Sutter, M., Zurbrïgg, R. P., Joss, E. E., and Oetliger, O. (1971). Cleft lip and choroideal coloboma associated with multiple hypothalamo-pituitary dysfunction. Journal of Clinical Endocrinology and Metabolism, 33, 934-939.

Correspondence to Professor Z. Laron, Institute of Pediatric and Adolescent Endocrinology, Beilinson Medical Center, Petah Tikva, Israel.

The following articles will appear in future issues of this journal:

Nonaccidental poisoning in childhood. J. B. G. Watson, J. M. Davies, and J. L. P. Hunter.

Familial occurrence of omphalocele suggesting sex-linked inheritance. S. Havalad, H. Noblett, and B. D. Speidel.

Quantitation of digital clubbing by shadowgram technique. D. Sinniah and A. Omar.

Prognostic factors in acute meningococcaemia. L. S. Lewis.

Congenital complete heart block in the newborn associated with maternal systemic lupus erythematosus and other connective tissue disorders. J. D. Hardy, S. Solomon, G. S. Banwell, R. Beach, V. Wright, and F. Howard.

Familial partial trisomy of the long arm of chromosome 3 (3q). C. Fear and A. Briggs.

Housing and mothering. Their effects upon the developmental levels of 3-year-old children. M. Pollak.

Conservative care of the newborn baby. T. H. Hughes-Davies. 